УДК 681.51

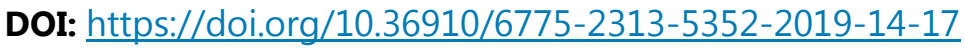

Мороз С.А. к.т.н., Пташенчук В.В. к.т.н., Приступа С.О. к.т.н., Кайдик О.Л. к.т.н.

Луцький національний технічний університет

\title{
ДОСЛІДЖЕННЯ РУХОВОЇ АКТИВНОСТІ ЛЮДИНИ ДЛЯ ВИЯВЛЕННЯ БІОСИГНАЛІВ ДЛЯ КЕРУВАННЯ БІОЕЛЕКТРИЧНИМ ПРОТЕЗОМ
}

В статті проведено аналіз рухової діяльності людини. Встановлено, щуо управління скорочувальною активністю м'язової клітини здійснюється за допомогою мотонейронів нервових клітин, тіла яких лежать в спинному мозку, а довгі відгалуження - аксони в складі рухового нерва підходять до м'язів, Біоелектричний вплив, переданий від центральної нервової системи до м'язів, відбивається підвищенням амплітуди в так званих рухових точках - місиях найбільшого скупчення рухомих одиниць. Якщо знімати біопотенціал в місиях розташування рухових точок, то ми можемо отримати вихідні сигнали для управління протезом. Електроміографією є основним методом дослідження нервово-м'язової системи за допомогою реєстрачії біоелектричних потенціалів. Електро-міографічні дослідження показують, щуо амплітуди біопотенціалів варіюються від 5-10 мкВ (м'яз в стані спокою) до 500-1000 мкВ (м'яз в збудженому стані). Основний діапазон частот біопотениіалів, щзо реєструються поверхневими електродами, становить 20-200 Гц, з максимумом близьким 50 - 100 Гц. Запропоновано структурну схему управління біоелектричним протезом кисті.

Ключові слова: рухова діяльність, біопотенціал, біоелектричний протез.

У формуванні рухів людини беруть участь всі рівні нервової системи (спинний мозок, різні утворення головного мозку, периферичні нерви, а також опорно-руховий апарат (ОРА) безпосередній виконавець рухів. Кістки і суглоби беруть участь в рухах пасивно, підкоряючись дії м'язів, але грають провідну роль в здійсненні опорної функції. Певна форма і будова кісток надають їм більшу міцність, запас якої на стиск, розтяг, вигин значно перевищує навантаження, можливі при повсякденній роботі ОРА. Рух проявляється у вигляді зміни положення суглоба (або суглобів) під впливом скорочення скелетних м'язів, які служать як би двигунами для кожного суглоба, або здійснюються без участі кістково-суглобового апарату одними м'язами. Скелетні м'язи здійснюють як статичну діяльність, фіксуючи тіло в певному положенні, так і динамічну, забезпечуючи переміщення тіла в просторі, окремих його частин відносно один одного. Обидва види м'язової діяльності тісно взаємодіють, доповнюючи один одного: статична діяльність забезпечує вихідний фон для динамічної. Як правило, положення суглоба змінюється за допомогою декількох м'язів різноспрямованої, у тому числі протилежної дії.

Складні рухи суглоба наповнюються узгодженим, одночасним або послідовним скороченням м'язів. Узгодженість (координація) особливо необхідна для виконання рухових актів, в яких беруть участь багато суглобів (наприклад, ходьба, біг, плавання тощо).

У світлі сучасних уявлень про механізми координації рухів, м'язи - не тільки виконавчий руховий апарат, а й своєрідний орган почуттів. В м'язових волокнах і сухожиллях є спеціальні нервові закінчення - рецептори, які посилають імпульси до клітин різних рівнів ЦНС. В результаті між нею і м'язами створюється замкнутий цикл: імпульси від різних утворень ЦНС, що йдуть по рухових нервах, викликають скорочення м'язів, а імпульси, що посилаються рецепторами м'язів, інформують ЦНС про кожен елемент і моменті рухів. Циклічна система зв'язків забезпечує точне управління рухами і їх координацію [1]. Хоча в управлінні рухами скелетних м'язів при здійсненні рухових актів беруть участь різні відділи ЦНС, провідна роль в забезпеченні їх взаємодії і постановці мети рухової реакції належить корі великих півкуль головного мозку, особливо при здійсненні складних рухів. У корі великих півкуль рухова i чутлива зони утворюють єдину систему, при цьому кожній м'язової групі відповідає певна ділянка цих зон. Подібний взаємозв'язок дозволяє точно виконувати рухи, співвідносячи їх 3 діючими на організм факторами навколишнього середовища.

Управління скорочувальною активністю м'язової клітини здійснюється за допомогою мотонейронів - нервових клітин, тіла яких лежать в спинному мозку, а довгі відгалуження аксони в складі рухового нерва підходять до м'язів (рис. 1). Увійшовши в м'яз, аксон розгалужується на безліч гілочок, кожна 3 яких підведена до окремого волокна. Таким чином, один мотонейрон управляє цілою групою волокон (так звана нейромоторна одиниця), яка працює як єдине ціле. Комплекс з мотонейроном і іннервируємими м'язовими волокнами 
називають руховою одиницею (РО). Середнє число волокон, які іннервують один мотонейрон, характеризує величину РО м'яза, а зворотну величину називають щільністю іннервації. Остання $\epsilon$ великою в тих м'язах, де рух невеликий і «тонкий» (очі, пальці, мова). Мале ії значення буде, навпаки, в м'язах з «грубими» рухами (наприклад, тулуб).

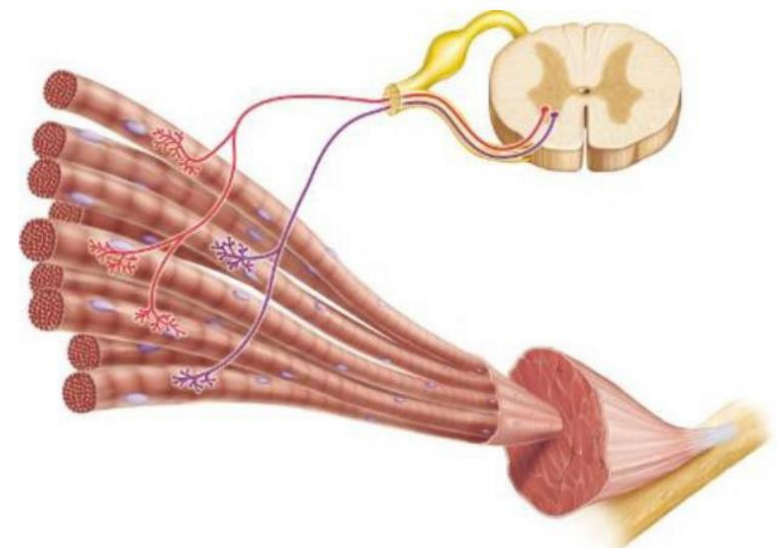

Рис. 1. Процес управління скорочувальною діяльністю м'язів

М'яз являє собою структурний елемент локомоторної системи з множинними зворотними зв'язками. У нервовій регуляції м'язової діяльності беруть участь мінімум три підсистеми. Перша підсистема визначає скоротливу функцію мускулатури. Вона складається 3 мотонейронів і м'язів з розташованими в них пропріорецепторами. Імпульсна інформація в ній поширюється від клітин передніх рогів спинного мозку до м'язів і від м'язових рецепторів в зворотному напрямку через задньокорінцеву систему до спинномозкового центру і знову до мотонейронів. Друга підсистема забезпечує оптимальний рівень збудливості пропріорецепторов. Третя підсистема, що складається з аксони колатералей мотонейронів $\mathrm{i}$ вставних нейронів Реншоу, призначена для саморегуляції мотонейронів [1].

Завдання і мета рухової дії формуються мисленням, що визначає спрямованість уваги і зусиль людини. До недавнього часу протези прикріплялися до людського тіла механічно і не мали ніякого зв'язку з нервовою системою. Вони могли згинатися в своїх залізних шарнірахсуглобах, але для виконання кожного руху власнику потрібно було тим або іншим чином регулювати поведінку свого протеза вручну, забезпечуючи зворотний зв'язок. Коли людині без кінцівки хочеться поворухнути пальцем, мозок генерує відповідний сигнал, який йде по нервах, що веде до м'язів кінцівки. Але, оскільки кінцівка відсутня, сигнал йде «в порожнечу». Але якщо по шляху «перехопити» нервові імпульси, то на цій основі після аналізу і обробки даних можна сформувати команди для управління протезом.

Біоелектричний вплив, переданий від центральної нервової системи до м'язів, відбивається підвищенням амплітуди в так званих рухових точках - місцях найбільшого скупчення РО. Область рухової точки є максимально збудливою ділянкою м'язу. Якщо знімати біопотенціал в місцях розташування рухових точок, то ми можемо отримати вихідні сигнали для управління протезом. Метод дослідження нервово-м'язової системи за допомогою реєстрації біоелектричних потенціалів в медицині прийнято називати електроміографією (ЕМГ). На рис. 2 приведена ЕМГ при збудженні м'язу.

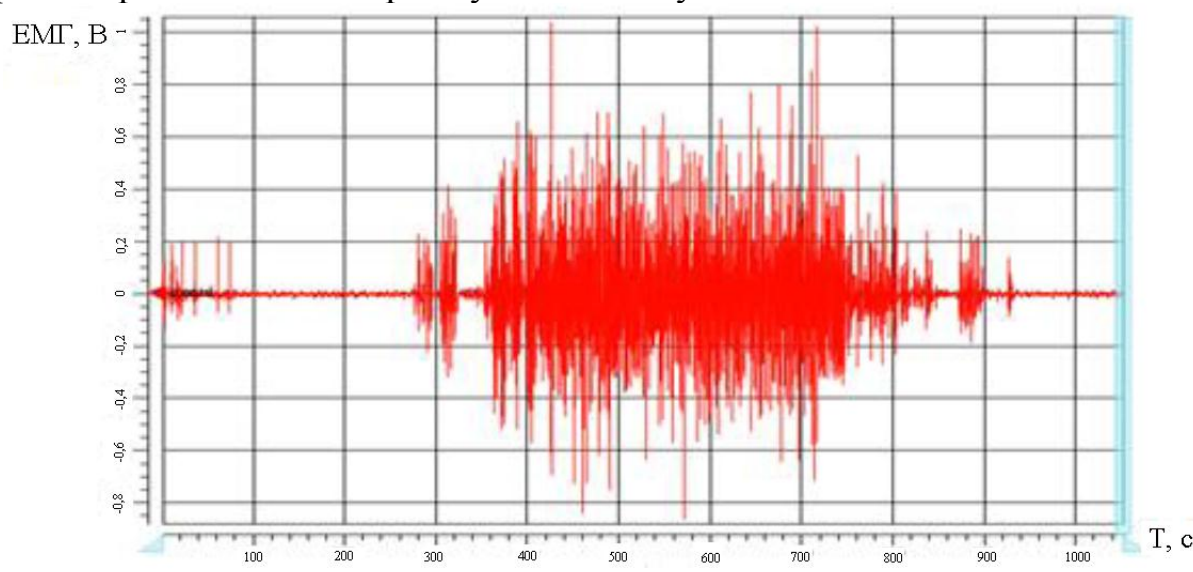

Рис. 2. ЕМГ при збудженні м'язу 
ЕМГ дослідження показують, що амплітуди біопотенціалів варіюються від 5-10 мкВ (м'яз в стані спокою) до 500-1000 мкВ (м'яз в збудженому стані). Основний діапазон частот біопотенціалів, що реєструються поверхневими електродами, становить 20200 Гц, 3 максимумом близьким 50 - 100 Гц [1].

Розрізняють поверхневу ЕМГ і голчасту ЕМГ (рис. 3) Поверхнева (глобальна, нашкірна, або сумарна ЕМГ) - це метод реєстрації та вивчення біопотенціалів м'язів у спокої і при їх активації шляхом відведення біоелектричної активності поверхневими електродами нашкірно над руховою точкою м'яза. Цей метод $є$ неінвазивним i безболісним і дозволяє оцінювати електричну активність м'язів глобально, тобто сумарно $[1,2]$.

Голчаста (або локальна ЕМГ) - метод реєстрації та вивчення біоелектричної активності рухових волокон і РО м'язу за допомогою голчастих електродів при їх введенні, в спокої, і при довільній активації м'язів. Метод $є$ інвазивним і болючим, однак дозволяє визначати такі механізми роботи нервово-м'язового апарату, які погано виявляються поверхневою ЕМГ.

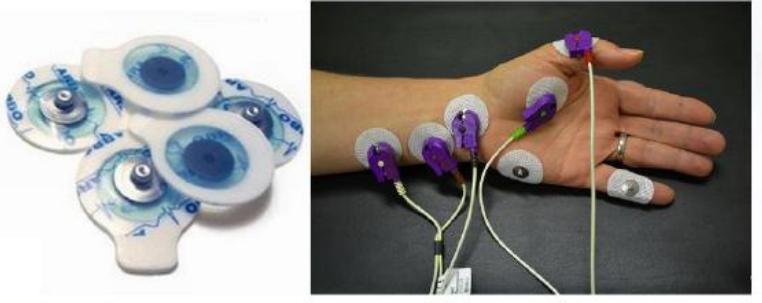

a

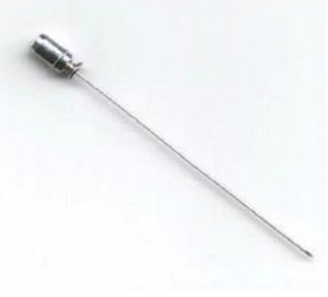

6

Рис. 3. Види електродів: а - поверхневі електроди, б - голчастий електрод

Одним 3 перспективних та ефективних методів управління протезами $\epsilon$ електроміографічний (міоелектричний) метод, який є більш безпечним для організму. Він використовує поверхневі електроди для зчитування електричної активності м'язів людини. Основною вимогою при використанні обраного методу управління є збереження активності і цілісності м'язового волокна, що відповідає за управління відсутньої кінцівки.

На рис. 4 представлена структурна схема біоелектричного протеза кисті. Основною функцією протеза $\epsilon$ згинання та розгинання пальців. Для реалізації даних процесів, використовується мікроконтролер (МК) і сервопривід.

За допомогою поверхневих електродів 3 культі пацієнта проводиться реєстрація біопотенціалів з м'язів передпліччя людини. Далі сигнал надходить на блок управління, в якому відбувається його перетворення з аналогової форми в цифрову.

Блок управління (рис. 5) перетворює сигнал 3 м'язів, і складається 3 підсилювача, смугового фільтра, підсилювача і випрямляча. Блок формування команд включає в себе мікроконтролер і сервопривід.

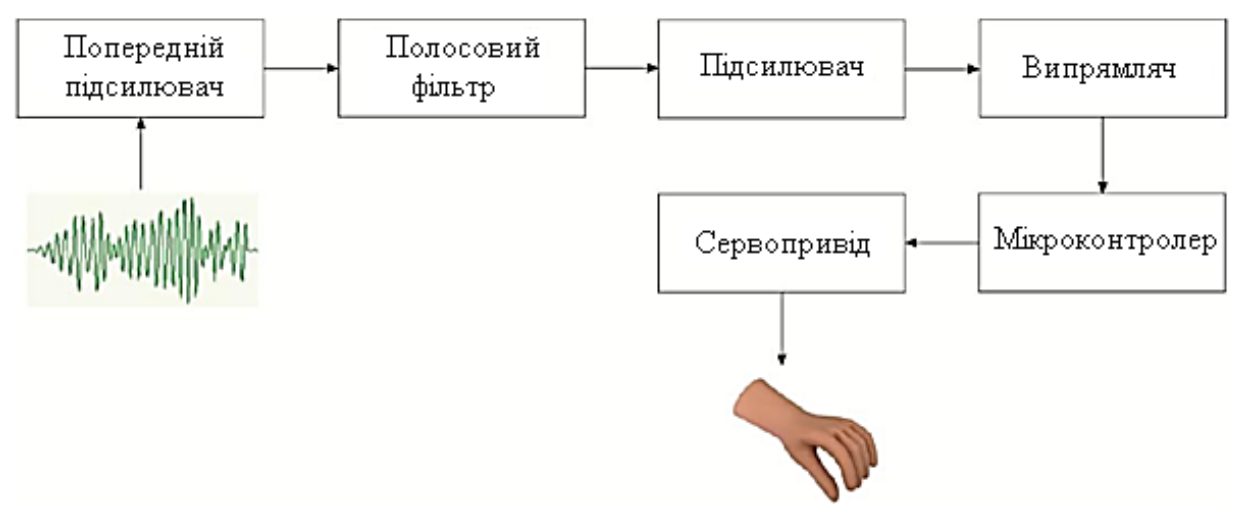

Рис. 5. Структурна схема блоку управління і блоку формування команд біоелектричним протезом кисті

Середнє значення амплітуди електроміограми коливається в межах 20-200 мкВ. 3 сигналом такої величини практично неможливо працювати, тому для подальшої роботи, біосигнал подається на підсилювач блоку управління. Для ЕМГ характерна хаотична шумова форма, отже, підсилюючи керуючий сигнал, посилюються i шуми. Для отримання інформативного сигналу, сигнал з підсилювача подається на фільтр. Область оптимальних 
частот ЕМГ лежить в діапазоні 20-500 Гц, тому доцільно буде використовувати смуговий фільтр.

Для усереднення сигналу і отримання позитивної частини напруги. Для того щоб виконати це завдання ставлять в схему двонапівперіодний випрямляч, який діє як обвідний детектор, що використовується для усунення сигналу і отримання позитивної частини напруги сигнал після підсилення і смугової фільтрації сигналу (рис. 6).

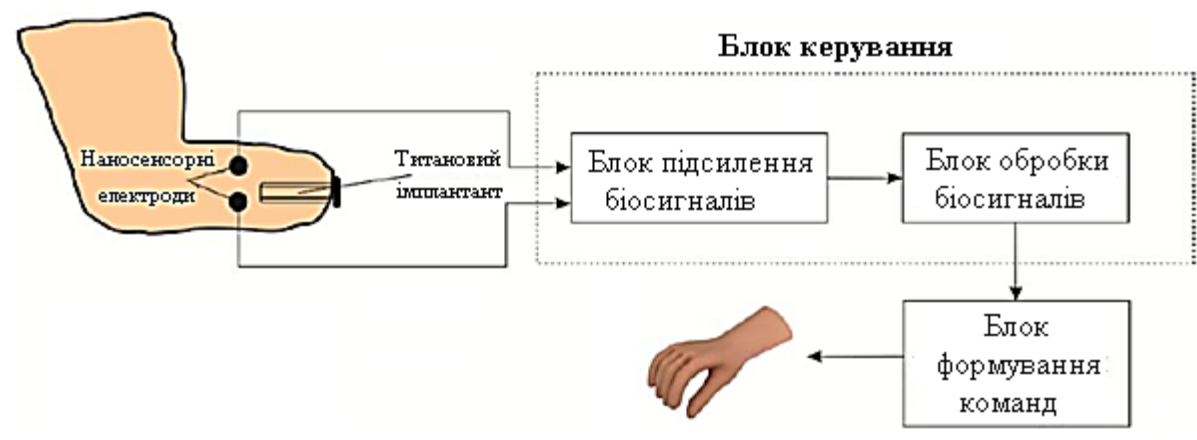

Рис. 4. Структурна схема управління біоелектричним протезом кисті

Потім обвідний детектор супроводжується низькочастотним фільтром для згладжування пульсацій в сигналі, що діє в якості інтегратора. Далі сигнал подається на вхід АЦП мікроконтролера і на виході ми повинні отримати перетворений аналоговий сигнал і цифровий, який буде визначати кут повороту механізму.

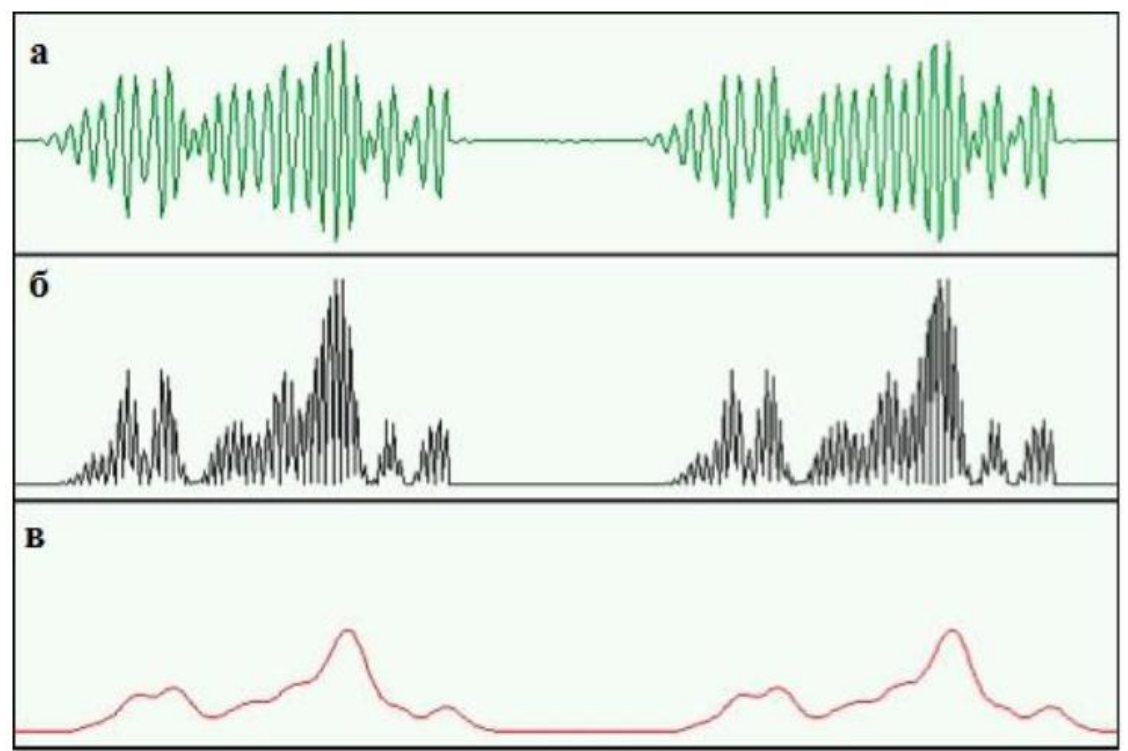

Рис. 6. а - сигнал з ЕМГ; б -підсилений і випрямлений сигнал; в -сигнал з виходу мікроконтролера

Мікроконтролер, порівнює амплітуду сигналу ЕМГ (20-200 мкВ), результат порівняння передає на сервопривід. Кут повороту сервоприводу регулюється тривалістю ЕМГ. Якщо на мікроконтролер надходить вхідний сигнал, нижче встановленого діапазону, значить, м'язи знаходяться в стані спокою і двигун приймає початковий стан до наступної активності м'язів. Діапазон значень, що регулюють роботу мікроконтролера, встановлюється для кожного пацієнта індивідуально.

Отже, біоелектричний вплив, переданий від центральної нервової системи до м'язів, відображається підвищенням амплітуди в так званих рухових точках - місцях найбільшого скупчення РО. Область рухової точки є максимально збудливим ділянкою м'язи. Якщо знімати біопотенціал в місцях розташування рухових точок, то ми можемо отримати вихідні сигнали для управління протезом. Використавши запропоновану структурну схемууправління біоелектричним протезом кисті отримаємо виконання основної рухової функції людської кисті руки - згинання та розгинання пальців. 


\section{Інформаційні джерела}

1. Бернштейн Н. А. Физиология движений и активность. М.: Наука, 1990. 689 с.

2. Н.А. Бернштейн. О построении движений. М., Машиностроение, 1975

3. А.И. Корендясев, С.В. Левин. Принципы построения захватных устройств с рекуперацией энергии. Проблемы машиностроения и автоматизации, 1990, № 3.

УДК 681.51

Мороз С.А. к.т.н., Пташенчук В.В. к.т.н., Приступа С.О. к.т.н., Кайдик О.Л. к.т.н. Луцкий национальный технический университет

\section{ИССЛЕДОВАНИЕ ДВИГАТЕЛЬНОЙ АКТИВНОСТИ ЧЕЛОВЕКА ДЛЯ ВЫЯВЛЕНИЯ УПРАВЛЯЮЩИХ БИОСИГНАЛОВ ДЛЯ УПРАВЛЕНИЯ БИОЭЛЕКТРИЧЕСКОЙ ПРОТЕЗЫ}

В статье проведен анализ двигательной деятельности человека. Установлено, что управление сократительной активностью мышечной клетки осуществляется с помощью мотонейронов - нервных клеток, тела которых лежат в спинном мозге, а длинные ответвления - аксоны в составе двигательного нерва подходят к мышцам, Биоэлектрическое влияние, переданное от центральной нервной системы в г. мыши, отражается повыпением амплитуды в так называемых двигательных точках - местах наибольшего скопления двигательных единиц. Если снимать биопотенциал в местах расположения двигательных точек, то мы можем получить выходные сигнальы для управления протезом. Электромиография является основным методом исследования нервно-мышечной системы с помощью регистрации биоэлекрических потенциалов. ЭМГ исследования показывают, что амплитуды биопотенцииалов варьируются от 5-10 мкВ (мьцица в состоянии покоя) до 500-1000 мкВ (мышиа в возбужденном состоянии). Основной диапазон частот биопотенииалов, регистрируемых поверхностными электродами, составляет 20-200 Ги, с максимумом около 50 - 100 Ги. Предложена структурная схема управления биоэлектрическим протезом кисти.

Ключевые слова: двигательная деятельность, биопотенциал, биоэлектрический протез.

UDC 681.51

Moroz S. , Ptashenchuk V., Pristupa S., Kaydik A.

Lutsk National Technical University

HUMAN MOVEMENT ACTIVITY EXAMINATION FOR THE DETERMINATION OF THE RELEVANT BIOSIGNALS FOR MANAGEMENT BY BIOELECTRIC PROTESIS

In the article the analysis of human motor activity is carried out. It was established that the management of contractile activity of the muscle cell is carried out with the help of motor neurons nerve cells whose bodies lie in the spinal cord, and long branches - the axons within the motor nerve are suitable for muscles, the bioelectric effect, transmitted from the central nervous system to $m$ 'utes, is reflected by an increase in the amplitude in the so-called motor points - the places of the largest accumulation of moving units. If we remove the biopotential in the locations of the motor points, then we can get the output signals for controlling the prosthesis. Electromyography is the main method of studying the neuromuscular system by registering bioelectric potentials. Electromyographic studies show that the amplitudes of biopotentials vary from 5-10 $\mu \mathrm{V}$ (muscle in rest) to 500-1000 $\mu \mathrm{V}$ (excited muscle). The main range of frequencies of biopotentials recorded by surface electrodes is $20-200 \mathrm{~Hz}$, with a maximum of about 50-100 $\mathrm{Hz}$. The structural scheme of bioelectric prosthesis control of the brush is proposed.

Key words: motor activity, biopotential, bioelectric prosthesis. 